\title{
IS IT BETTER TO BE SAFE THAN SORRY? THE CARTAGENA PROTOCOL VERSUS THE WORLD TRADE ORGANISATION
}

\author{
Anais Kedgley Laidlaw*
}

\begin{abstract}
One of the most important developments of the twenty-first century has been the emergence of biotechnology and genetic engineering. In response to this development, the Cartagena Protocol on Biosafety was negotiated, and entered into force in September 2003. The Cartagena Protocol sets up a regime governing the international movement of genetically modified organisms (GMOs) that aims to protect biodiversity from any adverse effects of genetically modified organisms. However, the Cartagena Protocol is not the only regime governing such movement. The World Trade Organisation (WTO) also covers the trade in GMOs, but has a different aim: to prevent limitations on such movement. As a result it is almost inevitable that a dispute concerning the trade in GMOs will occur. Therefore, harmonisation of the two agreements is highly desirable. One way to achieve this, which would then avoid the need for WTO reform, would be for the Cartagena Protocol to be used by the WTO as evidence of internationally accepted standards in relation to GMOs. However, given that the WTO would be unlikely to accept such a proposal, other solutions need to be explored.
\end{abstract}

\section{INTRODUCTION}

The latest developments in agriculture have enabled scientists to incorporate various traits from one species into other different plant and animal varieties. This new technology, called genetic engineering (GE), is advancing rapidly, with more than 28 million hectares of GE crops planted worldwide in $1999 .{ }^{1}$

* Submitted as part of the LLB(Hons) programme at Victoria University of Wellington.

1 Deborah Katz "The Mismatch Between the Biosafety Protocol and the Precautionary Principle" (2000) 13 Geo Int'l Envtl L R 949, 950. 
The possible benefits of GE are numerous. Proponents cite the ability of genetically modified organisms (GMOs) to be disease resistant and, potentially, to provide enough food to end world hunger. United States President Bush, at a 2003 biotechnology conference, claimed, "[w]e should encourage the spread of safe, effective biotechnology to win the fight against global hunger". ${ }^{2}$

However, opponents of GE claim that there has not been enough testing of GMOs to ensure that they are safe for humans and the environment. They point out that most testing to date has been to ensure that the GE crops will actually grow. ${ }^{3}$ There has been little testing of the long-term effects of GMOs on humans, animals and the environment. ${ }^{4}$ The New Zealand Royal Commission of Inquiry on Genetic Modification concluded, "little is yet known about the environmental impacts of GMOs". 5 Even today, over thirty years after products containing GMOs first appeared in supermarkets, scientists have yet to reach a consensus on whether GMOs are in fact fundamentally different from non-GMOs. ${ }^{6}$ Some scientists see GE as just an extension of natural breeding techniques, while others see GE as a drastic change in the whole makeup of a species or plant.

In light of these uncertainties, governments face a dilemma: how to make decisions on risks that are as yet impossible to ascertain? Should GMOs be banned until it can be established beyond question that they will cause no harm? Or should GMOs be treated in the same way as non-GMOs until there is some scientific consensus as to whether they are actually harmful?

In response to the uncertainty surrounding GMOs, both national and international regulatory structures have been put in place. This paper will examine the two principal international regulatory structures for the trade in GMOs: the system established under the World Trade Organisation (WTO), and the Cartagena Protocol on Biosafety (the Protocol). ${ }^{7}$

2 "Bush argues Africa harmed by Europe's GE Policies" (9 July 2003) New Zealand Herald Auckland 4.

3 Annette Cotter "If we are not sure about GM, we shouldn't do it" (19 July 2003) New Zealand Herald Auckland, 5.

4 It has often been claimed that there have been no adverse consequences from field releases of GMOs in the United States. In 1993, however, the data from the United States Department of Agriculture (USDA) field trials were evaluated to see whether they supported these safety claims. The Union of Concerned Scientists, which conducted the evaluation, found that the data collected by the USDA on small-scale tests had very little value for commercial risk assessment. Many reports fail to mention, much less measure, environmental risk: Vandana Shiva Stolen Harvest (South End Press, Cambridge (MA), 2000) 102.

5 Ministry for the Environment "GM Current Controls in NZ and the Royal Commission's Recommendations" (October 2001) Press Release; Report of the Royal Commission on Genetic Modification (Royal Commission on Genetic Modification, Wellington, 2002).

6 David J Schnier "Genetically Modified Organisms and the Cartagena Protocol" (2001) 12 Fordham Envtl L J 377, 382 .

7 Cartagena Protocol on Biosafety to the Convention on Biological Diversity (29 January 2000) 39 ILM 1027, also available at $<$ http://www.biodiv.org $>$ (last accessed 2 June 2005). 
The Protocol, which entered into force on 11 September 2003, was negotiated under the framework of the Convention on Biodiversity (the Convention). ${ }^{8}$ It sets up a regime governing the international movement of "living modified organisms" (LMOs). LMOs include GMOs and organisms produced by fusing cells from different taxonomic families. ${ }^{9}$

The Protocol's main concern is restricting the movement of GMOs in accordance with the precautionary principle. Put simply, the precautionary principle requires that if there is a lack of scientific certainty as to the effects of any action, then that action should be deferred. The Protocol attempts to address growing international concerns with GMOs by giving parties the right to restrict trade in GMOs until those uncertainties have been addressed.

The WTO, on the other hand, is a regime that regulates the international trade in all goods with the express intention of preventing any limitation on that trade. The WTO requires that its members should not restrict trade unless there is firm scientific evidence that such trade may be harmful to humans, animals or the environment.

Therefore, the two agreements appear to clash. The WTO has hinted that trade restrictions in a multilateral environmental agreement (MEA) such as the Protocol might violate WTO rules, ${ }^{10}$ thereby creating an immediate problem for countries that are parties to both these agreements. How should these countries manage their respective obligations under these two seemingly contradictory regimes?

New Zealand is a party to the Protocol and the WTO. Can New Zealand restrict its imports of GMOs from exporters such as the United States on the basis that there is scientific uncertainty as to the effects of GMOs on humans and the environment? This would appear permissible under the Protocol, but how would this affect New Zealand's obligations under the WTO?

The United States has been threatening to initiate a dispute at the WTO over GMOs for a number of years. The United States seems to be particularly concerned with the European Union's (EU) de facto moratorium on approving new GMOs. ${ }^{11}$ A host of big United States businesses that produce GMOs have lobbied the government fiercely. ${ }^{12}$ Some commentators claim that any

8 Convention on Biological Diversity (5 June 1992) 31 ILM 818.

9 Cartagena Protocol on Biodiversity, above n 7, art 3.

10 Thomas Cors "Biosafety and International Trade: Conflict or Convergence?" (2000) 2 Int J Biotechnology 27,34 .

11 Friends of the Earth "GM Trade War Looms" (12 May 2003) Press Release.

12 Friends of the Earth, above n 11. 
complaint taken to the WTO by the United States over GMOs would be tantamount to an attempt by the United States to undermine the Protocol. ${ }^{13}$

This article will firstly examine the Protocol and issues raised during the negotiation process. It will then focus on the precautionary principle and the Protocol's relationship with the WTO. The final parts of this article will address how the WTO might deal with a dispute over trade in GMOs and suggest possibilities for WTO reform.

\section{THE CARTAGENA PROTOCOL}

The Protocol entered into force on the 11 September 2003. As at July 2005, 122 countries have ratified the Protocol. New Zealand ratified the Protocol on 24 February 2005, and it entered into force in New Zealand on 26 May 2005.

\section{A Objective of the Protocol}

The objective of the Protocol, set out at article 1, is:

$[\mathrm{T}] \mathrm{o}$ contribute to ensuring an adequate level of protection in the field of the safe transfer, handling and use of living modifier organisms resulting from modern biotechnology that may have adverse effects on the conservation and sustainable use of biological diversity, taking also into account risks to human health, and specifically focussing on trans boundary movements.

In addition, both the preamble and article 1 of the Protocol states that its main objective is to ensure protection against LMOs in accordance with the precautionary principle contained in principle 15 of the Rio Declaration on Environment and Development (Rio Declaration). ${ }^{14}$

\section{B Scope of the Protocol}

The Protocol applies to two general categories of LMOs:

- $\quad$ LMOs intended for release into the environment (such as fish, plants and seeds); and

- LMOs intended for use in food or feed, or for processing (such as soymilk and cornflakes). ${ }^{15}$

However, only LMOs intended for release into the environment are covered by the operational sections of the Protocol. ${ }^{16}$ This is because those LMOs are thought to pose a greater threat to

13 Centre for International Environmental Law "The WTO 5th Ministerial Conference in Cancun" (27 June 2003) Press Release.

14 Rio Declaration on Bio Diversity (5 June 1992) A/CONF/151/26/REV1; 31 ILM 874, art 15.

15 Article 7(2) of the Protocol clearly sets out that "intentional introduction into the environment" does not refer to GMOs intended for direct use as food or feed, or for processing. Article 11 of the Protocol deals with these types of GMOs. 
biodiversity and native species as they can mutate, migrate and multiply. In addition all LMOs that are pharmaceuticals for humans are specifically excluded from the Protocol. ${ }^{17}$

The EU argued that all LMOs should be covered by the Protocol, as there is potential for all LMOs to be introduced into the environment. However, the United States vetoed this suggestion on the basis that it would create too heavy a burden on exporters. ${ }^{18}$

\section{The Key Element of the Protocol: the AIA}

Articles 7 to 12 of the Protocol set up an "advance informed agreement system" (AIA) that has been described as "the backbone of the Protocol."19 The AIA requires an exporting country to obtain the consent of another country before shipping living LMOs to that country for the first time. Under the Protocol, the exporting country must notify the importing country's national authority. The importing country must then acknowledge receipt of the notification, and decide whether or not to accept the shipment within a certain period of time.

A risk assessment must be carried out for all decisions made in relation to the acceptance of LMO shipments. ${ }^{20}$ A party can accept the shipment with certain conditions, prohibit the import or request additional information from the exporter. In addition the Protocol establishes a "Biosafety Clearing-House", which is an internet site where all decisions are recorded. Article 10 of the Protocol requires that any party who agrees to import a particular LMO must communicate that decision to the importer and to a Biosafety Clearing House within 270 days of the original notification. However, the Protocol is clear that a failure to notify does not imply consent. ${ }^{21}$

The parties to the Protocol have the ability to declare some LMOs safe through a meeting of the parties. The effect of such a declaration is that the LMO concerned is then not subject to the AIA procedure. This mechanism is likely to prove to be an efficient way for parties to deal with noncontroversial LMOs. In addition LMOs intended for contained use and LMOs in transit are similarly exempt from the AIA procedure.

16 Cartagena Protocol on Biosafety, above n 7, art 7(1) and (2). This means that the Protocol effectively fails to cover 90 per cent of GMO goods.

17 Cartagena Protocol on Biosafety, above n 7, art 5.

18 Schnier, above n 6, 408.

19 Aaron Cosbey and Stas Burgiel The Cartagena Protocol on Biosafety: An analysis of Results (Briefing note, International Institute for Sustainable Development, Winnipeg, 2000) 7.

20 Cartagena Protocol on Biosafety, above n 7, art 15.

21 Cartagena Protocol on Biosafety, above n 7, art 15(5). 


\section{LMOs for Food, Feed or Processing}

Articles 11 and 18 of the Protocol covers LMOs that are shipped in bulk as commodities for use as human food or animal feed, or in processed goods (for example corn, cotton, and soy). ${ }^{22}$ These GMOs are not covered by the AIA procedure. Instead, such shipments are simply subject to labelling requirements which require accompanying documentation stating that the shipment "may contain" LMOs that are not intended for international introduction into the environment.

This requirement may be helpful for countries in the process of enacting domestic GMO labelling schemes. However, the details were to be worked out before 2005. To date they are still being negotiated. The United States fought for the extended timeframe in order to avoid the cost of mandatory segregation for as long as possible, on the basis that such a system was simply not feasible. $^{23}$

\section{E Non-Parties}

The Protocol requires that trade in LMOs with non-parties must be carried out in a manner "consistent with the objective of the Protocol". ${ }^{24}$ The Protocol also states that parties should encourage non-parties to adhere to the Protocol, and to contribute information to the Biosafety Clearing-House. ${ }^{25}$ Any attempt to ban trade in LMOs with non-parties would almost certainly have led to a WTO challenge, because treaties cannot bind non-parties. However, the requirement that trade be carried out in a manner consistent with the Protocol has the potential to affect non-parties, in particular the United States.

\section{F The Negotiations and the Positions of the Parties}

Negotiations for the Protocol commenced in 1995. While not a party to the Convention, the United States exerted considerable influence on the scope of the Protocol by participating in negotiations. ${ }^{26}$ Its involvement was intended to ensure that the Protocol had as limited an effect as possible, in order to protect the United States biotechnology industry. ${ }^{27}$ The primary objective of the United States was the subordination of the Protocol to the WTO rules, so that international trade in GMOs would not be disrupted.

22 Cartagena Protocol on Biosafety, above n 7, art 7.3.

23 Cosbey and Burgiel, above n 19.

24 Cartagena Protocol on Biosafety, above n 7, art 24(1).

25 Cartagena Protocol on Biosafety, above n 7, art 24

26 Friends of the Earth, above n 11.

27 Schnier, above n 6, 403. 
One hundred and thirty five countries participated in the negotiations for the Protocol and quickly divided themselves into different negotiating groups. The first group was known as the "Like Minded Group." It consisted of all developing countries with the exception of Argentina, Chile, and Uruguay. The Like-Minded group was in favour of a strong Protocol that would not be subordinate to the WTO, and would have a robust statement of the precautionary principle. ${ }^{28}$

The next group, called the "Miami Group", comprised Canada, Australia, Argentina, Uruguay, Chile and the United States. This group consisted of all the major GMO exporting countries, and was led by the United States. The Miami Group favoured a weak Protocol that would not disrupt international trade in GMOs and argued for a "savings clause" to ensure that the Protocol would not displace or trump any other international agreements, particularly the WTO.

While participating in the negotiations, the United States continually sought to have the issue of trade in GMOs shifted to the WTO's mandate. In a communication dated 27 July 1999, the US, with Japan's support, recommended that a GMO group should be formed within the WTO. ${ }^{29}$ However, the WTO declined to address the GMO issue, mainly due to lack of support from the EU. ${ }^{30}$ That decision has lent greater weight to the Protocol: by declining to deal with the issue itself, the WTO has effectively consented to the formation of a separate agreement on GMOs.

The EU Member States formed their own group in the Protocol's negotiations. The EU's objective was the inclusion of the precautionary principle in the Protocol. The EU objected to the savings clause sought by the Miami Group, arguing that it would create problems for importing parties that denied imports citing the precautionary principle. ${ }^{31}$

During the final stages of negotiations, the precautionary principle became a key issue and effectively drew out the negotiations for a number of years. ${ }^{32}$ However, after protracted negotiation, the United States withdrew its opposition to the inclusion of the precautionary principle in the operational part of the text, and agreement on the draft text of the Protocol was finally reached in January 2000. The agreed text of the Protocol was opened for signature at the United Nations Environment Project headquarters in Nairobi from 15 to 26 May 2000.

28 Schnier, above n 6, 404

29 Fiona Macmillan WTO and the Environment (Sweet and Maxwell, London, 2001) 168.

30 World Development Movement "Rethinking Trade Rules after Seattle: An Agenda for Reform" (10 March 1999) Press Release.

31 Carolina Lasen Diaz, Foundation for International Law and Development, "The Precautionary Principle since Rio - Biotechnology and the Cartagena Protocol" (International Environmental House, Geneva, 16 May 2002).

32 Diaz, above n 31, 3. 


\section{THE PRECAUTIONARY PRINCIPLE}

It was agreed early on in the negotiations that the Protocol would include the precautionary principle, but the real issue was how strongly it would feature. The EU fought for the inclusion of the principle in the operational part of the text, and won. The result is that the Protocol contains one of the strongest references to the precautionary principle to date, ${ }^{33}$ and is the first protocol of its kind to include the precautionary principle in the operational part of the protocol, rather than just making reference to it in the preamble. ${ }^{34}$ As a result the Protocol has been described as "propelling the precautionary principle to the forefront of international environmental law". .35

The Protocol also incorporates the precautionary principle into a party's decision-making process under the AIA and gives members the ability to take trade-restrictive action to prevent potential adverse effects of LMOs on biodiversity and human health.

Article 10(6) of the Protocol sets out that: ${ }^{36}$

Lack of scientific certainty due to insufficient relevant scientific information and knowledge regarding the extent of the potential adverse effects of a living modified organism on the conservation and sustainable use of biological diversity in the Party of import, taking also into account risks to human health, shall not prevent that Party from taking a decision, as appropriate, with regard to the import of the living modified organism in question ... in order to avoid or minimize such potential adverse effects.

To fully understand the effect and the significance of the incorporation of the precautionary principle in the Protocol, some background to the principle is necessary.

\section{A The Precautionary Principle: what is it?}

Since the 1980s, the precautionary principle has been widely used in international environmental agreements, including the ground-breaking Rio Declaration, a non-binding agreement created by the international community for the promotion of sustainable development which has become one of the most important texts in international environmental law. ${ }^{37}$

33 Schnier, above n 6, 413.

34 Terence P Stewart and David S Johanson "A Nexus of Trade and the Environment: The Relationship Between the Cartagana Protocol on Biosafety and the Agreement on the Application of Sanitary and Phytosanitary Measures of the World Trade Organisation" (2003) 14 Colo J Int'l Envtl L \& Policy 1, 25.

35 Schnier, above n 6, 413.

36 Cartagena Protocol on Biosafety, above n 7, art 10(6).

37 United Nations Framework Convention on Climate Change (9 May 1992) 1771 UNTS 30822, art 3(3); Rio Declaration on Bio Diversity, above n 14, art 15. 
Many different versions of the precautionary principle have been used in international and domestic agreements. The principle can be broken into several elements. ${ }^{38}$ The first is the level of risk that justifies precautionary action. Most agreements that deal with activities with a high level of risk and little benefit, such as the dumping of hazardous waste, have tended to have lower thresholds of risk to justify precautionary action. For example, the Bamako Convention, which deals with the movement of waste, sets the risk level at activities that "may cause harm to humans or the environment". ${ }^{39}$ Other agreements which deal with risky yet beneficial activities often employ higher risk-triggering levels. Examples are the Convention on Climate Change and the Rio Declaration, which both require "threats of serious or irreversible damage" to trigger precautionary action. ${ }^{40}$ By contrast, the level of risk identified in the Protocol is "potential adverse effects", ${ }^{41}$ which is significantly lower than the Rio Declaration, and signals that precautionary action is easily justified under the Protocol.

The second element of the precautionary principle is the action to be taken when precaution is justified. The Bamako Convention is very wide and requires "prevention" of the effects, ${ }^{42}$ whereas the Rio Declaration requires only "cost effective measures". ${ }^{43}$ The Protocol allows a party to make a "decision as appropriate with regard to import in order to avoid or minimize such potential adverse effects" when precaution is triggered. ${ }^{44}$ Significantly, the Protocol does not require any consideration of the benefits of an activity or its cost effectiveness. In this way the Protocol concentrates exclusively on the potential impact on biodiversity.

The third element of the precautionary principle is the level of scientific uncertainty. The Rio Declaration and the Convention on Climate Change each requires "lack of full scientific certainty" for the precautionary principle to be triggered. The Protocol requires only "certainty", 45 suggesting that parties to the Protocol do not need scientific consensus to trigger the precautionary principle.

38 Katz, above n 1, 957.

39 Bamako Convention (30 January 1991) 2101 UNTS 36508, art 4(3)(f).

40 United Nations Framework Convention on Climate Change, above n 37, art 3(3); Rio Declaration on Bio Diversity, above n 14, art 15.

41 Cartagena Protocol on Biosafety, above n 7, art 10(6).

42 Bamako Convention, above n 39, art 4(3)(f).

43 Rio Declaration on Bio Diversity, above n 14, art 15.

44 Cartagena Protocol on Biosafety, above n 7, art 10(6).

45 Cartagena Protocol on Biosafety, above n 7, art 10(6). 


\section{B How do we Make Decisions on Risks that are Uncertain?}

While the Protocol allows parties to make decisions with regard to imports based on the precautionary principle, it also requires that all decisions be made in accordance with a risk assessment. ${ }^{46}$ A risk assessment is the evaluation of the likelihood and severity of harm to the environment or human health from exposure to a hazardous substance. ${ }^{47}$ Such assessments traditionally involve a "sound science" approach and ignore what is unknown or cannot be measured. In the past, risk assessments have often stood in the way of protecting human health and the environment.

Article 15(3) of the Protocol states that parties can require exporters to carry out the required risk assessment which importantly, will enable developing countries to enact measures based on the precautionary principle, even if they do not have the means themselves to perform risk assessments (which can be expensive and time consuming).

It is, however, hard to reconcile the precautionary principle with the weight of evidence that is typically used by scientists in making risk assessments. Under the Protocol, risk assessments are to be carried out on a case-by-case basis and "in a scientifically sound manner". ${ }^{48}$ The Protocol goes on to note, however, that lack of scientific knowledge or consensus should not be interpreted as indicating that there is or is not a risk. ${ }^{49}$ The Protocol does not prescribe what view is to be taken of a risk assessment, and it does not identify any minimum standards to be adopted by a decision maker. This suggests that the requirement to perform a risk assessment under the Protocol is procedural only.

As a result, it seems possible for a party to the Protocol to conduct a risk assessment in accordance with the Protocol, find that there is no scientific evidence that the particular GMOs have any negative effects, and still ban their importation. Thus, it is unclear how the obligation to perform a risk assessment specifically ties in with the precautionary principle.

\section{Possible Benefits of GMOs}

Although the Protocol states, in the preamble, that it "recognises that modern biotechnology has great potential for human well being", it makes no mention of the possible benefits of GMOs in the operative part of the text or in the definition of the precautionary principle.

46 Cartagena Protocol on Biosafety, above n 7, art 15.

47 Dorothy Nelkin, Philippe Sands and Richard B Stewart "Genetically Modified Organisms: Forward the International Challenge of Genetically Modified Organism Regulation" (2000) 8 NYU Envtl LJ 523, 534.

48 Cartagena Protocol on Biosafety, above n 7, annex III, para 3.

49 Cartagena Protocol on Biosafety, above n 7, annex III, para 4. 
This is a significant omission given that many people consider that the potential benefits of GMOs outweigh any of the potential risks. ${ }^{50}$ Article 26 of the Protocol states that, in making a decision with regard to import, parties may take into account "socio-economic considerations arising from the impact of LMOs on the conservation and sustainable use of biological diversity, especially with regard to the value of biological diversity to indigenous and local communities". While this does not directly mandate a consideration of the benefits of GMOs, the fact that GMOs have the potential to improve the global food supply means that this benefit could be a consideration in making an import decision in accordance with the Protocol. However, article 26 is voluntary and parties are not required to take such considerations into account.

\section{Is the Precautionary Principle Appropriate for the Trade in GMOs?}

It has been argued that the precautionary principle is only appropriate in contexts where the risks or potential risks of an activity outweigh the benefits. ${ }^{51}$ Is the trade in GMOs such a context? One commentator concludes that it is not, and argues that the use of the precautionary principle in the Protocol will result in unnecessary restraints on trade, either because of unfounded fears of biotechnology or because of veiled attempts at protectionism. ${ }^{52}$ In addition, there are many opponents of the inclusion of the principle who claim that it is not knowledge-promoting and will stifle invention and innovation in GE.

However, because it will probably be a long time before the health and environmental effects of GMOs are known, a precautionary approach seems to be appropriate in this context. In that regard, it should be emphasised that the main obligations under the Protocol are limited only to GMOs that are to be intentionally introduced into the environment, and not to the majority of GMOs (such as those intended for use in food).

\section{E The Status of the Precautionary Principle at International Law}

Many commentators have argued that the inclusion of the precautionary principle in the operational part of the Protocol, coupled with its incorporation into nearly every international agreement on the environment since the Rio Declaration, indicates that it has become a principle of customary international law. ${ }^{53}$ Aaron Cosbey, Director of Trade and Investment at the Institute for Sustainable Development argues that while the status of the principle in 2000 was "less than clear", the Protocol "makes it clearer now". 54

50 Schnier, above n 6,386 .

51 Katz, above n 1, 952.

52 Katz, above n 1, 982.

53 Warwick Gullett "Environmental Protection and the 'Precautionary Principle': A Response to Scientific Uncertainty in Environmental Management" (1997) EPLJ 52, 57.

54 Cosbey and Burgiel, above n 19, 12. 
Other commentators argue that, notwithstanding its incorporation into the Protocol, the precautionary principle is not a rule of customary international law, primarily because there is no common definition of it. ${ }^{55}$ However, regardless of its status, it is clear that the Protocol is revolutionary in its operationalisation of the precautionary principle in an MEA.

\section{THE PROTOCOL AND THE WTO}

Whether to include the precautionary principle was not the only issue for the negotiators of the Protocol. The other major issue during negotiations was the relationship of the Protocol with the WTO. As previously mentioned, the United States was determined that the Protocol should be subordinate to the WTO, so that the international trade in GMOs would not be disrupted.

Because WTO rules aim to prevent limitation on the movement of goods, the fact that the Protocol includes a precautionary principle of such scope, means that the two systems appear to conflict. The specific WTO rules that relate to trade in GMOs will be examined in detail below but, basically, WTO rules require scientific justification for any limitation on trade. As a result, because there is no scientific certainty in regard to GMOs, any action pursuant to the Protocol could potentially breach WTO rules. There is, therefore, a clear need to establish how the two systems relate to each other.

\section{A The Savings Clause in the Protocol}

The Protocol provides some guidance on how it should affect other international agreements in the form of a savings clause in the preamble of the text. However, as explained in greater detail below, the savings clause does not settle the question of how the Protocol relates to WTO rules.

The draft Protocol, as advocated by the United States, included a savings clause in the body of the text. However, after lengthy negotiations during the Montreal session, the parties agreed to shift the savings clause to the preamble of the Protocol. The resulting savings clause is, however, ambiguous, reflecting the sensitivity of the compromise struck. It states: ${ }^{56}$

Recognizing that trade and environment agreements should be mutually supportive with a view to achieving sustainable development,

Emphasizing that this Protocol shall not be interpreted as implying a change in the rights and obligations of a Party under any existing international agreements,

Understanding that the above recital is not intended to subordinate this Protocol to other international agreements.

55 Gullett, above n 53, 57.

56 Cartagena Protocol on Biosafety, above n 7, preamble. 
The fact that the savings clause appears in the preamble and not the operative part of the Protocol signals that the parties intended it to have less force. However the Vienna Convention on the Law of Treaties clearly states that the preamble of a treaty, while not directly enforceable, is still part of the treaty for the purposes of interpretation. ${ }^{57}$

Because of its ambiguity, the savings clause in the Protocol and has been interpreted in many different ways. A United States Department of State Fact Sheet on the Protocol, stated that the savings clause shows that "countries participating in the negotiations had no intention of using the Protocol to alter their existing rights and obligations." 58

The United States claims that the savings clause in the Protocol "makes it crystal clear that the treaty does not alter - and fully preserves - the rights and obligations of governments under the rules of the World Trade Organization ...". ${ }^{59}$ However, in support the United States refers only to the second paragraph of the savings clause and effectively ignores the third.

That the savings clause states that the Protocol will not be subordinate to other agreements means that the United States cannot categorically claim that WTO rules trump the Protocol. In fact, it could be argued that on the basis that the savings clause is redundant, the three paragraphs all seem ultimately to cancel each other out. ${ }^{60}$

The result of the savings clause in the Protocol was that the United States could claim a victory with the first part of the paragraph and the EU could also claim a victory with the third. A number of commentators claim that the lack of clarity in the savings clause is "an entrée to GMO-related trade disputes", ${ }^{61}$ and could also "give lawyers at the WTO an excuse to ignore the Protocol altogether". ${ }^{62}$

Article 2(4) of the Protocol also appears to deal with the relationship between the Protocol and other agreements. It states:

Nothing in this Protocol shall be interpreted as restricting the right of a Party to take action that is more protective of the conservation and sustainable use of biological diversity than that called for in this

57 Vienna Convention on the Law of Treaties (23 May 1969) 11SS UNTS 18232, art 31(2).

58 United States Department of State "Fact sheet: Update the Cartagena Protocol on Biosafety" (2001) Press Release.

59 David B Sandalow The Biosafety Protocol: What It Does and Does Not Do (United States Department of State International Information Programs, Washington DC, 2000).

60 Stewart and Johanson, above n 34, 24

61 International Centre for Trade and Sustainable Development "Biosafety Protocol Welcomed Cautiously" (8 February 2000) Press Release.

62 Kristen Dawkins "Biotech - From Seattle to Montreal and Beyond: The Battle Royale of the $21^{\text {st }}$ Century" (February 2000) available at <http://www.biotech-info.net> (last accessed 3 June 2005). 
Protocol, provided that such action is consistent with the objective and the provisions of this Protocol

and is in accordance with that Party's other obligations under international law.

This clause seems to suggest that the protections provided for in the Protocol are a minimum, and that only agreements which provide for greater protection can trump the Protocol. On that basis it could be argued that WTO rules, which provide for a lower level of protection than the Protocol, should be subordinate to the Protocol.

On balance however, it must be concluded that both clauses in the Protocol leave open the question of the Protocol's relationship with other international agreements. As noted by one commentator during negotiations "the compromise struck in Montreal is so delicate, lawyers may never be able to sort out which treaty should prevail". ${ }^{63}$ Because the relationship between the two agreements cannot be clarified by reference to the texts alone, it is likely that if a dispute arose as to how the two agreements relate, that dispute would need to be referred to some form of dispute resolution process.

\section{B Where would a Dispute between the Two Agreements Go?}

A dispute over the conflict between the Protocol and the WTO would most likely be referred to the WTO Disputes Panel. The WTOs Committee on Trade and Environment, which was established in 1994 by a Ministerial decision, has stated that any dispute over a trade action taken under an environmental agreement should be settled through the environmental agreement if both sides to the dispute have signed that agreement. ${ }^{64}$ But if one side to the dispute has not signed the environment agreement, then the dispute must go to the WTO. ${ }^{65}$

Two parties to the Protocol could, in theory, use the dispute settlement process in the Protocol, to resolve a dispute between the Protocol and the WTO rules. However, this process remains undefined and has not yet been tested. ${ }^{66}$ It is likely that any dispute will have to be resolved through the WTO, even where both parties to the dispute are members of the Protocol.

\section{A Hypothetical Dispute: New Zealand and the United States}

If New Zealand, acting consistently with the Protocol, banned the import of certain GMOs from the United States, it would be open to the United States to take a case to the WTO claiming that New Zealand had breached WTO rules. The next part of this paper will focus on such a scenario. In the WTO dispute settlement process, a complaint may be brought by an affected member against

63 Dawkins, above n 62.

64 Macmillan, above n 29, 12.

65 World Trade Organisation "The Environment: A New High Profile" < http://www.wto.org/> (last accessed 3 June 2005).

66 Stewart and Johanson, above n 34, 34. 
any other member country for violations of the WTO agreements. In addition, other member countries with a substantial interest in a particular dispute may participate as third parties. ${ }^{67}$ Because the GMO issue is so controversial, it is likely that other countries would be drawn into such a conflict. While the WTO dispute process is government-to-government, private companies with a substantial interest in the dispute often work closely with their government to advance their interests. This would certainly be the case for the United States, which is home to most of the largest GMO producers in the world, and there is evidence that those companies have already lobbied their government intensively in relation to this issue. ${ }^{68}$

In certain circumstances the WTO has allowed private, non-governmental entities to file "friend of the court" briefs in dispute settlement proceedings. ${ }^{69}$ It is likely that this would be attempted by the many environmental agencies that have a substantial interest in GE generally.

Article 3(2) of the WTO's Dispute Settlement Understanding (DSU), which sets out the procedure for hearing disputes at the WTO, states that "recommendations and rulings of the disputes body cannot add to or diminish the rights and obligations provided in the covered agreements".70 Thus, it is clear that the disputes body's only role is to interpret the WTO agreements.

\section{The Two Levels of the WTO Disputes System}

The WTO disputes body consists of a Disputes Panel (the Panel) and an Appellate Body. Appeals to the Appellate Body are limited to legal interpretations that have been made by the Panel, ${ }^{71}$ giving the Appellate Body a clear judicial quality. ${ }^{72}$ However, there is a perception that the Appellate Body has not been entirely consistent or predictable in its approach. ${ }^{73}$ The Appellate Body consists of seven permanent members who are specialists in law and international trade. Usually those specialists will have more experience with trade considerations than with biotechnology and environmental issues. ${ }^{74}$ The members of the Appellate Body are selected from a list maintained by the WTO Secretariat. Member countries are able to propose names of governmental and non-governmental individuals for inclusion on the list, and all additions to the list

67 Understanding on Rules and Procedures Governing the Settlement of Disputes (WTO, Uruguay Round Agreement, annex 2); (15 April 1994) 31 ILM 1226, art 10.

68 Friends of the Earth, above n 11.

69 United States - Import Prohibition of Certain Shrimp and Shrimp Products (Shrimp Turtles) (12 October 1998) WT/DS58/AB/R para 13 (Appellate Body).

70 Understanding on Rules and Procedures Governing the Settlement of Disputes, above n 67, art 3(2).

71 Understanding on Rules and Procedures Governing the Settlement of Disputes, above n 67, art 17(6).

72 Macmillan, above n 29, 16.

73 Macmillan, above n 29, 17.

74 Understanding on Rules and Procedures Governing the Settlement of Disputes, above n 67, art 8. 
must be approved by the WTO. ${ }^{75}$ Once a decision has been reached, the Appellate Body and the Panel can still be overruled by the WTO in General Council, as the General Council has exclusive authority to accept Panel interpretations. ${ }^{76}$

In making decisions the Appellate Body is able to call upon scientific evidence, ${ }^{77}$ and can request an advisory report in writing from "an expert review group". ${ }^{78}$ While not expressly stated in the DSU, the Panel and the Appellate Body will usually consult the parties to a dispute in relation to the source of their scientific information. ${ }^{79}$ Scientific sources would be particularly significant for a dispute concerning GMOs, as there is widespread disparity in scientific opinion. The ability of the Appellate Body to call on one expert review group (and not another) would therefore have the effect of elevating one possible scientific view over other equally plausible views.

\section{THE WTO AND GMOS}

This section of the paper will look at the WTO rules that would be considered by the Panel or Appellate Body in dealing with the hypothetical example between the United States and New Zealand discussed above. ${ }^{80}$ There are three WTO agreements relevant to the trade of GMOs. These are the General Agreement on Tariffs and Trade (the GATT), ${ }^{81}$ the WTO Agreement on Technical Barriers to Trade (the TBT Agreement) ${ }^{82}$ and the WTO Agreement on the Application of Sanitary and Phytosanitary Measures (the SPS Agreement). ${ }^{83}$

\section{A The GATT}

All products, including industrial and agricultural products, are subject to GATT's provisions. The agreement is based on the core WTO principles, including: ${ }^{84}$

75 Understanding on Rules and Procedures Governing the Settlement of Disputes, above n 67, art 8.

76 Understanding on Rules and Procedures Governing the Settlement of Disputes, above n 67, art 17(14).

77 Understanding on Rules and Procedures Governing the Settlement of Disputes, above n 67, art 13(1).

78 Understanding on Rules and Procedures Governing the Settlement of Disputes, above n 67, art 13.

79 Understanding on Rules and Procedures Governing the Settlement of Disputes, above n 67, art 11(2).

80 See Part IV C A Theoretical Dispute: New Zealand and the United States.

81 General Agreement on Tariffs and Trade (30 October 1947) 55 UNTS 187.

82 WTO Agreement on Technical Barriers to Trade (12 April 1979) WTO/MTN/NTM/W/192/Rev S.

83 Agreement in the Application of Sanitary and Phytosanitary Measures (15 December 1993) WTO/MTN/FA II-A1, A4.

84 General Agreement on Tariffs and Trade 1994 (WTO, Uruguay Round Agreement, annex 1A); (15 April 1994) 33 ILM 1153. 
- Non-discrimination - a country should not discriminate between its trading partners or between foreign products;

- Like treatment for like products - products that are alike in their final form should be regulated consistently in relation to trade;

- Objectivity - countries should avoid arbitrary or discriminatory measures and any regulation affecting trade should be underpinned by science.

The basic object of GATT is to ensure that technical regulations or standards do not create unnecessary obstacles to international trade. However, there are a number of exceptions to these principles in GATT.

In the hypothetical example above, the Panel would probably look first at whether the trade measures used by New Zealand violated any of the substantive articles of GATT. Assuming they did, the Panel would then consider whether one of the exceptions to GATT's substantive rules applied.

A refusal by New Zealand to import certain GMOs pursuant to the Protocol could violate a number of GATT provisions. First, it might violate the "like treatment for like products" requirement. The WTO rules are only concerned with products in their final form, and are not concerned with the process by which a product is made, unless that process in some way affects the final product. The view of the United States Food and Drug Administration's is that GE food is substantially equivalent to normal food. The USFDA has claimed that "these new foods ... will be every bit as safe as the foods now on store shelves". 85

In the case of European Communities - Measures Affecting Asbestos and Asbestos Containing Products (Asbestos), ${ }^{86}$ the Appellate Body indicated that it would allow the inclusion of environmental or human health aspects of a product in a "like product" decision, stating "we are very much of the view that evidence relating to the health risks associated with a product may be pertinent in an examination of the "likeness under article III:4 of the GATT". 87 However, the Appellate Body added that this suggestion was "a narrow one, limited only to the circumstances of this case, and confined to chrysotile asbestos". 88

85 United States Foods and Drug Administration "Genetic Engineering: Fast Forwarding to Future foods" (12 February 1998) Press Release.

86 European Communities - Measures Affecting Asbestos and Asbestos Containing Products (Asbestos Case) (12 March 2001) WT/DS135/AB/R (Appellate Body).

87 Asbestos Case, above n 86, para 113.

88 Asbestos Case, above n 86, para 153. 
The application of Asbestos to circumstances outside an asbestos context is limited because in that case it was concluded that there was scientific certainty about the adverse effects of asbestos on human health. Given the fact that there is no scientific certainty as to the health effects of GMOs on humans, Asbestos would suggest that GMOs should be considered substantially equivalent to nonGMOs. Accordingly, a refusal to import GMOs would likely violate GATTs "like treatment for like products" requirement.

Such a refusal may also constitute a "quantitative restriction" according to WTO rules. The WTO requires that countries avoid arbitrary or discriminatory measures in trade. In the case of United States - Import Prohibition of Certain Shrimp and Shrimp Products (Shrimp Turtles) ${ }^{89}$ it was argued, and accepted, that the United States was breaching this rule because it would not import shrimp harvested using certain methods. ${ }^{90}$ The case concerned a shrimp import ban that the United States had applied against countries where shrimp fishermen were not using "turtle excluder devices". These devices involved trapdoors attached to shrimp nets that allow the majority of sea turtles to escape. The case held that the blanket ban amounted to a quantitative restriction. Thus, if New Zealand refused to import GMOs while continuing to import non-GMOs it may be held to be employing arbitrary or discriminatory measures.

A refusal to import GMOs is also likely to breach the GATT rule of "objectivity", which requires that any regulation affecting trade should be underpinned by science. As has been discussed, as yet there is little definite scientific evidence as to potential harms associated with GMOs.

\section{B GATT Exceptions}

Article XX(b) of the GATT enables member states to enact legislation that creates barriers to trade necessary to protect human, animal or plant life or health. The SPS and TBT Agreements set out specific rules for determining the legitimacy of such measures.

To date, no dispute in relation to the trade in GMOs has reached the WTO, so it is unclear under which agreement any such dispute would be decided. It appears likely, however, that it would fall under the SPS Agreement, ${ }^{91}$ which deals with health and safety issues, because the main concern in relation to GMOs is their effect on the health of humans and the environment. The other relevant agreement, the TBT Agreement, applies to situations where products are banned by a country for reasons other than health and safety risks. Accordingly, for the purposes of this paper, it is assumed that any dispute would fall under the SPS Agreement. ${ }^{92}$

89 Shrimp Turtles, above n 69.

90 Shrimp Turtles, above n 69, para 187.

91 Stewart and Johanson, above n 34, 32.

92 This is the view of other commentators, for example: Stewart and Johanson, above n 34, 32. 


\section{The SPS Agreement}

The SPS Agreement emerged out of the Uruguay round of GATT and was implemented in $1995 .{ }^{93}$ It was designed to expand the operation of article XX(b) of GATT in respect of food safety and health standards. The SPS Agreement is essentially concerned with placing limitations on the introduction of such measures. ${ }^{94}$

Article 2 provides that SPS measures may be applied only to the extent necessary to protect human, animal or plant life or health, must be "based on scientific principles", 95 and may not be "maintained without sufficient scientific evidence". ${ }^{96}$ The SPS Agreement also provides that a measure must not "arbitrarily or unjustifiably discriminate between members where identical or similar provisions apply"97 and may not "be applied in a manner that would constitute a disguised restriction on international trade". 98

Where a WTO member acts consistently with all these requirements there is a presumption that it has complied with the GATT. ${ }^{99}$ However, one commentator has pointed out that because this is only a presumption there is still uncertainty about the relationship between the GATT and the SPS Agreement. ${ }^{100}$ The WTO seems to have indicated that where a measure violates the SPS Agreement, it cannot fall within the exception created by GATT article XX(b). ${ }^{101}$ However, it is not clear whether a measure which does not comply with the SPS Agreement could in fact fall within the other article XX exceptions. The most likely scenario is that in the event of a conflict between the agreements then the GATT would be subordinate to the SPS Agreement.

The SPS Agreement encourages countries to use measures that are consistent with international standards and specifically states that any SPS measures based on international standards are "presumed to be consistent" with the requirements of the SPS Agreement. ${ }^{102}$ Annex A of the SPS Agreement defines the international standards, guidelines and recommendations as the following:

93 Agreement on the Application of Sanitary and Phytosanitary Measures, above $\mathrm{n} 83$.

94 Macmillan, above n 29, 140.

95 Agreement on the Application of Sanitary and Phytosanitary Measures, above n 83, art 2(2).

96 Agreement on the Application of Sanitary and Phytosanitary Measures, above n 83, art 2(2).

97 Agreement on the Application of Sanitary and Phytosanitary Measures, above n 83, art 2(3).

98 Agreement on the Application of Sanitary and Phytosanitary Measures, above n 83, art 2(3).

99 Agreement on the Application of Sanitary and Phytosanitary Measures, above n 83, art 2(4)

100 Macmillan, above n 29, 116.

101 European Community - Measures Concerning Meat and Meat Products (Beef Hormones) (16 January 1998) WT/DS48/AB/R and WT/DS26/AB/R (Appellate Body).

102 Agreement on the Application of Sanitary and Phytosanitary Measures, above n 83, art 3(2). 
A for food safety, the standards, guidelines and recommendations established by the Codex Alimentarius Commission (Codex);

B for animal health, the standards, guidelines and recommendations developed by the International Office of Epizootic;

C for plant health, the international standards, guidelines and recommendations developed by the Secretariat of the International Plant Protection Convention; and

D for matters not covered by the above organisations, appropriate standards guidelines and recommendations promulgated by other relevant international organisations open for membership by the Committee.

While the SPS Agreement encourages members to be consistent with international standards it also allows members to maintain or introduce measures which result in higher standards if they can provide scientific justification for the higher standard. ${ }^{103}$ Such justification requires members to perform risk assessments.

One commentator argues that the strict requirement of scientific evidence to justify measures that are not based on international standards lacks a foundation in either domestic or international environmental law and "fails to encompass the multiplicity of considerations necessary for an appropriate analysis of health and environmental measures". ${ }^{104}$ Of note, there is nothing in the SPS Agreement allowing members to take into consideration any non-scientific factors, for example socio-economic considerations.

\section{Codex}

Codex is the international organisation charged with creating international standards in relation to food safety under the SPS Agreement. Codex was created in 1963 by the Food and Agriculture Organisation of the United Nations and the World Health Organisation to develop food standards, guidelines and codes of practice to promote coordination of all food standards among international governmental and non-governmental organisations. Codex achieves this by consensus of all member parties. Before the incorporation of Codex into the SPS Agreement all standards created by Codex were voluntary. However, its inclusion in the SPS Agreement means that Codex standards for GMOs will be binding in any related disputes and, in this respect, Codex has become politicised.

In 1993, Codex began the task of developing standards for GMOs by setting up the Ad Hoc Intergovernmental Task Force on Foods derived from Biotechnology. Unfortunately there is still no consensus on appropriate standards for GMOs. By May 2001 the Task Force had only agreed on

103 Agreement on the Application of Sanitary and Phytosanitary Measures, above n 83, art 3(3).

104 Layla Hughes "Limiting the Jurisdiction of Dispute Settlement Panels: The WTO Appellate Body Beef Hormone Decision" (1998) 10 Geo Int'l Envtl L Rev 915, 916. 
certain very basic definitions and there had been no progress on any concrete standards. Most of the member countries' negotiating positions under Codex mirror their positions in regard to the Protocol: the EU is pushing for Codex to adopt the precautionary principle, and the United States is pushing for no such adoption.

One commentator has argued that, under existing circumstances, it is doubtful whether Codex will be able to achieve the consensus required to produce standards for GMOs. ${ }^{105}$ Codex has only on very few occasions arrived at standards for any product where there is scientific uncertainty relating to the effects of that product on human health. That commentator concludes, "GE food labeling within the framework of Codex has the makings of a stalemate". ${ }^{106}$ Another commentator describes that process as "long and protracted with no international standard in sight". ${ }^{107}$

\section{E Are International Standards a Good Idea?}

Some commentators claim that reference to international standards in the SPS Agreement is a positive move towards international harmonisation. Others see the inclusion as a cause for concern, claiming that deference to international standards creates a "downward harmonisation" towards the lowest level of international protection.

There is, however, nothing in the SPS Agreement that prevents upward harmonisation, as international bodies may adopt strict national standards. However, the culture of the WTO would suggest that lowest common denominator standards better conform with the WTO's fundamental objective to reduce measures that restrict trade.

\section{F The Protocol as Evidence of an Internationally Accepted Standard for GMOs}

While there are currently no Codex standards that would be relevant to New Zealand in any action pursuant to the Protocol, New Zealand could argue that for the purposes of the SPS Agreement, the WTO should use the Protocol itself as evidence of internationally accepted standards required under the SPS Agreement. The Appellate Body has stated that: ${ }^{108}$

The ultimate goal of the harmonisation of SPS measures is to prevent the use of such measures for arbitrary or unjustifiable discrimination between Members or as a disguised restriction on international trade, without preventing members from adopting or enforcing measures which are both "necessary to

105 Nicholas Kalaitzandonakes and Peter Phillips "GM Food Labeling and the Role of the Codex" (2000) 3 AgBioForum 188.

106 Kalaitzandonakes, above n 105, 191.

107 Don Buckingham "The labelling on GM Foods - the Link between Codex and the WTO" (2000) 3 AgBioForum 209.

108 Beef Hormones, above n 101, para 177. 
protect" human life and health and "based on scientific principles", and without requiring them to

change their appropriate level of protection.

While many commentators view the three organisations in Annex 1 of the SPS Agreement as an exhaustive list, it is arguable that until Codex succeeds in setting standards in relation to GMOs, other indications of such standards, in particular the Protocol, could be used by the WTO. In the hypothetical dispute between the United States and New Zealand, New Zealand could argue that by acting in accordance with the Protocol, it is acting consistently with internationally accepted standards as required by the SPS Agreement.

Parties to the Protocol include most of the powerful Western states (apart from the United States) and many significant developing states, including India. Thus it can be argued that it is indicative of an internationally accepted standard in relation to GMOs. However, it could equally be argued that, because the United States is not a party to the Protocol but has extensive interests at stake in relation to the issue, the Protocol is not evidence of an internationally accepted standard. On the other hand, while the United States is not a formal party to the Protocol, the fact that it participated throughout the entire negotiations process, and had such a significant impact on the final terms of the Protocol, makes it effectively a de facto party.

However, even if it could be argued that the United States is a de facto party to the Protocol, the express reference to Codex in the SPS Agreement makes it unlikely that the WTO would accept such a solution.

\section{G Is Codex Relevant?}

Alternatively it is possible to argue that while the SPS Agreement requires Codex to formulate standards in relation to food safety, the Protocol is concerned with food safety. Rather the Protocol's main focus is the protection of biodiversity, and could therefore fall within article 1(d) of the SPS Agreement, which states that, for matters not covered by the organisations set out in the SPS Agreement, other relevant international organisations' standards can be used. ${ }^{109}$ It may be easier to argue that the Protocol could be considered such an organisation.

\section{H What if there are no International Standards?}

Because there are currently no Codex standards in place for GMOs, and the WTO is unlikely to accept the Protocol as evidence of such standards, any ban of GMOs by New Zealand would require scientific justification through a risk assessment judged to be consistent with the SPS Agreement.

109 Cartagena Protocol on Biosafety, above n 7, art 1(d). 


\section{Risk Assessment under the SPS Agreement}

The SPS Agreement provides that SPS measures must be based on an assessment of the risks. ${ }^{110}$ However, it does not set out specifically what is required for a risk assessment. In the recent case of European Community - Measures Concerning Meat and Meat Products (Beef Hormones), ${ }^{111}$ the Appellate Body examined those requirements. ${ }^{112}$

Beef Hormones involved a situation similar to the hypothetical New Zealand example and has been described by one commentator as the prelude to a dispute related to trade in GMOs. ${ }^{113}$ Beef Hormones concerned a decision by the EU not to import US beef on the basis that the beef contained artificial growth enhancing hormones that could potentially have adverse effects on human health.

At the Appellate Body, the EU claimed that its decision not to import beef was justified on the basis of the precautionary principle, which the EU claimed was a principle of customary international law. ${ }^{114}$ The United States argued that the EU's refusal breached the SPS Agreement because it was not based on existing international standards or supported by science. ${ }^{115}$

\section{J Burden of Proof}

The Appellate Body first considered which party bore the burden of proof and held that the complaining party must demonstrate a prima facie case, and then the burden shifts to the state imposing the measures to show that they are justified and consistent with the SPS Agreement. ${ }^{116}$ This is different to the Protocol which provides that an importing party can require the exporter to carry out a risk assessment.

\section{K Risk Assessment}

Next, the Appellate Body examined what was involved in a risk assessment and held that::117

We believe that Article 5.1, when contextually read as it should be, in conjunction with and as informed by Article 2.2 of the SPS Agreement, requires that the results of the risk assessment must sufficiently

110 Agreement on the Application of Sanitary and Phytosanitary Measures, above n 83, art 5(1).

111 Beef Hormones, above n 101.

112 Beef Hormones, above n 101, 69-73.

113 Paulette L Stenzel "Why and How the WTO must Promote Environmental Protection" (2002) 13 Duke Env L \& Pol'y F 1, 20.

114 Beef Hormones, above n 101, para XVI.

115 Beef Hormones, above n 101, para XLIII.

116 Beef Hormones, above n 101, para IV.

117 Beef Hormones, above n 101, para 98. 
warrant - that is to say, reasonably support - the SPS measure at stake. The requirement that an SPS measure be "based on" a risk assessment is a substantive requirement that there be a rational relationship between the measure and the risk assessment.

In addition, the Appellate Body concluded that a party must take into account a risk assessment at the time of enacting a measure, and that measure must be "based on" a risk assessment, meaning that the outcome of the risk assessment must reasonably support the measure at issue. ${ }^{118}$ The Appellate Body also held that a risk assessment must be scientific and specifically targeted at the measure concerned. ${ }^{119}$ This is very different to a risk assessment under the Protocol, as the Protocol does not appear to require a rational relationship between a risk assessment and the measure taken.

The Appellate Body reasoned that the bulk of the evidence produced by the United States and the EU supported a conclusion that the hormones were safe. The Appellate Body chose to ignore the EU's evidence on the carcinogenic potential of the beef hormones on the basis that it was too general and because the EU had not performed a risk assessment should be discarded. ${ }^{120}$

The Appellate Body took a "maximum use" of scientific information approach to risk assessment, favouring the majority of the evidence produced. Its reasoning suggests that an SPS measure will be inconsistent with the SPS Agreement unless it is justified by a specifically focussed scientific study.

\section{The Protocol and Risk Assessments}

Like the SPS Agreement, the Protocol, at article 10, requires parties to complete a risk assessment before making a decision with regard to import. However, the Protocol allows parties to make import decisions through risk management and the precautionary principle. There is a great difference between the focussed scientific analysis and justification required by the WTO and the "relative amorphous nature" of the precautionary principle in the Protocol. ${ }^{121}$ It would seem that while it is possible under the Protocol to have zero tolerance for GMOs in accordance with articles 10(6) and 11(6), such an approach could never be permissible under the SPS Agreement.

118 Beef Hormones, above n 101, para 98.

119 Beef Hormones, above n 101, para 98-99.

120 John Ewers "Duelling Risk Assessments: Why the WTO and Codex threaten United States Food Standards" (2000) 30 Envtl L 387, 388.

121 Brett Grosko "GE and International Law: Conflict or Harmony? An Analysis of the Biosafety Protocol, GATT, and the Agreement on the Application of Sanitary and Phytosanitary Measures" (2001) 20 Va Envtl L J 295, 324 


\section{The Beef Hormones Case and the Precautionary Principle}

Despite Beef Hormones providing an opportunity to make an authoritative decision on the status of the precautionary principle at international law, both the Panel and the Appellate Body avoided such a decision.

The Appellate Body held that: ${ }^{122}$

The status of the precautionary principle in international law continues to be the subject of debate among academics, law practitioners, regulators and judges. The precautionary principle is regarded by some as having crystallized into a general principle of customary international environmental law.

Whether it has been widely accepted by Members as a principle of general or customary international law appears less than clear.

Accordingly, the precautionary principle did not, in the Appellate Body's view justify measures that were inconsistent with the SPS Agreement. ${ }^{123}$ It was asserted however, that the precautionary principle was "reflected" in the SPS Agreement at article 5(7). ${ }^{124}$ Article 5(7) allows members to introduce measures that are not supported by "sufficient scientific evidence" on a provisional basis, subject to further evidence being obtained.

Article 5(7) allows for provisional measures that are based on "available pertinent information", but the Appellate Body made it clear that the principle was only relevant as a provisional measure and could last only until a state had an opportunity to undertake a more objective risk assessment, ${ }^{125}$ a clear indication of the extent to which the precautionary principle is unpopular with the WTO.

\section{$N$ Beef Hormones-Conclusion}

The ruling of the Appellate Body in Beef Hormones highlights the conflict between the concept of a risk assessment contained in the SPS Agreement and the precautionary principle. The Protocol gives parties the ability to manage risks through the precautionary principle. ${ }^{126}$ The SPS Agreement does not give parties this ability except in a limited form under article 5(7).

It is clear from this case that to comply with the SPS Agreements a party must conduct a risk assessment and that risk assessment must provide a scientific basis for any SPS measure. One commentator claimed "the very high standards [set by the $\mathrm{AB}$ ] for what is a valid risk assessment

122 Beef Hormones, above n 101, para 28 (emphasis in original).

123 Beef Hormones, above n 101, para 125.

124 Beef Hormones, above n 101, para 124.

125 Beef Hormones, above n 101, para 124.

126 Jan McDonald "Big Beef up or Consumer Health Threat?: The WTO Food safety Agreement, Bovine Growth Hormone and the Precautionary Principle" (2000) 15 EPLJ 115, 125. 
led to [the EU losing]". ${ }^{127}$ Another claimed that the case "elevated the risk assessment process to a position of inappropriate pre-eminence". 128

\section{O Japan-Measures Affecting Agricultural Products}

The case of Japan - Measures Affecting Agricultural Products (Japan) ${ }^{129}$ further considered article 5(7) of the SPS Agreement. In Japan, Japan had enacted a law that prohibited the importation of eight agricultural products originating from the United States on the grounds that they were potential hosts to codling moths, identified as a pest by Japan. ${ }^{130}$ However, the law allowed the import ban to be lifted if an exporting country proposed an alternative quarantine treatment that would protect Japan from the codling moth. The United States claimed that the testing requirement was inconsistent with the SPS Agreement and took its case to the WTO. Japan claimed that its laws were justified on the basis of the precautionary principle, as expressed in article 5(7) of the SPS Agreement. $^{131}$

The Appellate Body held that article 5(7) operates only as "a qualified exemption from the obligation not to maintain SPS measures without sufficient scientific evidence". ${ }^{132}$ It stated that a member could only adopt a provisional measure under article 5(7) if that measure was: ${ }^{133}$

(1) imposed in respect of a situation where "relevant scientific information is insufficient"; and

(2) adopted "on the basis of available pertinent information".

The Appellate Body went on to add that any such measure may not be maintained unless the member that adopted the measure: ${ }^{134}$

(1) $\quad \operatorname{seek}[\mathrm{s}]$ to obtain the additional information necessary for a more objective assessment of risk"; and

127 "The State of Trade Law and the Environment: Key Issues for the next Decade" (Working paper, International Institutee for Sustainable Development, Winnipeg and the Centre for International Environmental Law, Washington DC, 2003) 42.

128 McDonald, above n 126, 125.

129 Japan - measures affecting agricultural products (Japan case) (22 February 1999) WT/DS76/AB/R (Appellate Body).

130 The prohibited products were apples, cherries, peaches, walnuts, apricots, pears, plums and quince.

131 Japan case, above n 129, para 92.

132 Japan case, above n 129, para 80.

133 Japan case, above n 129, para 89.

134 Japan case, above n 129, para 89. 
(2) "review[s] the ... measure accordingly within a reasonable period of time."

The Appellate Body determined that as Japan had not sought additional information upon which to conduct a risk assessment, and had failed to review its provisional policies within four years, it had violated the second part of Article 5(7). ${ }^{135}$

One commentator has claimed that the effect of Japan is that article 5(7) creates an "illusory" benefit for WTO members as it requires members that seek to rely on it to continually gather and assess all new information as it becomes available. ${ }^{136}$

It can be concluded that both the Protocol and the SPS Agreement (though article 5.7) permit countries to impose import restrictions based on the precautionary principle. However, while the Protocol does not set any time limits on the use of such measures, the SPS Agreement only allows the precautionary principle to be used provisionally, where there is uncertainty, while further risk assessment is undertaken. As demonstrated by Japan, this period of time is short and information gathering by the member country must begin immediately. The case provides another example of the conflicting approaches of the two agreements.

\section{OTHER INTERNATIONAL LAW}

In the settlement of disputes at the WTO the Panel and the Appellate Body base their decisions on the WTO Agreements and previous decisions of the AB. Recently however, both the Appellate Body and the Panel have referred to other international instruments in their decisions. ${ }^{137}$ One commentator, in regards to this trend wrote, "The WTO is no longer a watertight ship. The Appellate Body has clearly moved to referencing other branches [of international law], most notably international environmental law, for interpreting and applying WTO Agreements". ${ }^{138}$ On this basis, in the hypothetical dispute between New Zealand and the United States, New Zealand could argue that although its actions may breach WTO rules, because it is acting pursuant to the Protocol, the WTO should take the Protocol into account in its decision.

The next section of the article will examine other international law that could be used by the WTO in dealing with a dispute over the trade in GMOs.

\section{A The WTO and MEAs}

As stated above, the WTO's Appellate Body has yet to consider a dispute concerning a trade restrictive measure pursuant to an MEA that conflicts with WTO rules. Thus it is unclear whether

135 Japan case, above n 129, para 92.

136 "The State of Trade Law and the Environment: Key Issues for the next Decade", above n 127, 42 and 44.

137 Shrimp Turtles, above n 69, para 124.

138 "The State of Trade Law and the Environment: Key Issues for the next Decade", above n 127, 33. 
the Appellate Body would just look at the WTO agreements in deciding such a case or whether it might take into account the relevant terms of the MEA.

Several prior WTO decisions have commented on how MEAs, such as the Protocol, might be dealt with by the WTO. These Appellate Body decisions show that the WTO favours multilateral treaties that restrict trade for environmental purposes over unilateral bans.

In the Shrimp Turtles decision, ${ }^{139}$ the Appellate Body was highly critical of the United States for imposing a unilateral ban, rather than negotiating a multilateral agreement for the protection of sea turtles. The Appellate Body claimed that because the United States had not entered into negotiations with other parties to establish a multilateral agreement for the protection of sea turtles, its actions constituted unjustifiable discrimination. ${ }^{140}$ The Appellate Body went on to conclude that multilateral instruments are preferable to unilateral trade restrictions, and held that: ${ }^{141}$

[In rejecting this appeal] We have not decided that the environment is of no significance to members of the WTO. Clearly, it is. We have not decided that the sovereign nations that are members of the WTO cannot adopt effective measure to protect endangered species, such as sea turtles. Clearly, they can and should. We have not decided that sovereign states should not act together bilaterally, plurilaterally or multilaterally, either within the WTO or in other international fora, to protect endangered species or to otherwise protect the environment. Clearly, they should and do.

In response, the United States emphasised that it had entered into a regional agreement for the protection of sea turtles called the Regional Inter-American Convention. This agreement actually ended up counting against the United States as the Appellate Body concluded that the fact the United States had negotiated with some parties only, and not all affected parties, increased the discrimination against parties left out of the negotiations. ${ }^{142}$ Thus it can be concluded that for an MEA to be acceptable to the WTO all interested parties must be members.

New Zealand could cite Shrimp Turtles as evidence that trade restrictions incorporated into a MEA should be considered favourably by the WTO. However, one commentator argues that the case, far from endorsing MEAs, simply creates a new hurdle for the success of any environmental trade restriction. She claims that its only effect is that, "unilateral measures will [now] be looked at askance". 143

139 The facts of the case are discussed above at Part V A The GATT.

140 Shrimp Turtles, above n 69, paras 167-170.

141 Macmillan, above n 29, 96.

142 Shrimp Turtles, above n 69, para 167.

143 Macmillan, above n 29, 95. 
What does this mean for the Protocol? As discussed the United States - one of the world's biggest exporters of GMOs - is not a party to the Protocol. It could argue that because the Protocol does not include all affected parties, it should be discounted by the WTO. On the other hand, it could be argued that the participation of the US in negotiations means that its interests have been sufficiently taken into account.

In the World Trade Report for 2003 the WTO stated that: ${ }^{144}$

[p]ursuant to the Shrimp Turtles ruling by the AB, the will to resolve an environmental problem through the conclusion of an MEA, or good faith efforts to negotiate with the non-party concerned, may also

help tip the balance for the defending WTO member.

It could, as a consequence, be argued that the United States involvement in the negotiations for the Protocol is sufficient for the WTO to look favourably on the Protocol.

One commentator has argued that as a result of Shrimp Turtles the WTO must give legal weight to MEAs, on the basis that the WTO cannot call for them on the one hand and ignore them on the other. ${ }^{145}$ He concludes that Shrimp Turtles "brings the use of MEAs into a source that can be analogised into an international standard". ${ }^{146}$ Another commentator has argued that, in relation to the Protocol "the WTO may be willing to concede the difficulty of challenging the authority of another widely accepted international agreement". ${ }^{147}$ Thus, the WTO may hold trade restrictive measures pursuant to the Protocol to be legitimate, on the basis that the Protocol is an MEA that has been endorsed, to some extent, by nearly all affected parties.

\section{B The CTE}

The Committee on Trade and Environment (CTE) has also commented on the effects of MEAs in relation to the WTO. In the conclusions reached at the WTO's 1996 Singapore Ministerial Conference, the CTE stated that it fully supported multilateral solutions to global environmental problems and urged WTO members to avoid unilateral actions. ${ }^{148}$ However, the CTE also claimed that there was no need to change WTO provisions to provide increased accommodation for MEAs. In the event of a conflict in the WTO over the trade measures prescribed in an MEA (in particular

144 World Trade Organisation "World Trade Report" (14 August 2003) Press Release, 186.

145 "The State of Trade Law and the Environment: Key Issues for the next Decade", above n 127, 25.

146 "The State of Trade Law and the Environment: Key Issues for the next Decade", above n 127, 32.

147 Macmillan, above n 29, 109.

148 WTO Committee on Trade and Environment Report (1996) of the Committee on Trade and Environment (WT/CTE/1, Geneva, 1996). 
against a WTO member that is not a party to the MEA), the CTE expressed its belief that WTO dispute settlement provisions are satisfactory for tackling such problems. ${ }^{149}$

\section{Customary International Law}

The WTO is also bound by rules of customary international law. ${ }^{150}$ The Appellate Body has, in several decisions, ruled that the Vienna Convention is part of its jurisprudence, and that the WTO agreements are to be interpreted in accordance with it. ${ }^{151}$ The next part of the article will look at what the Vienna Convention provides for in relation to the application of successive treaties. Where two treaties overlap, the Vienna Convention provides general principles of interpretation that help to determine which of the two treaties should prevail.

\section{The Vienna Convention}

The starting point for any interpretation of the relationship between conflicting international agreements is the words of the agreements themselves. Article 30 of the Vienna Convention provides guidance on the application of successive treaties relating to the same subject matter, but it is only "residuary" in application. If the parties expressly indicate that a certain agreement prevails the Vienna Convention has no application. As noted above, the Protocol does not expressly address its relationship with WTO rules.

\section{The same subject matter?}

Article 30 of the Vienna Convention states that it should be used to interpret "successive treaties relating to the same subject matter". ${ }^{152}$ The background to the Vienna Convention suggests that the Convention is not relevant to interpretation of completely separate agreements that happen to overlap. ${ }^{153}$ The first issue under article 30 is, therefore, whether the WTO rules and the Protocol relate to the same subject matter. The WTO is concerned with trade whereas the Protocol relates to biodiversity.

It may be possible to argue that the existence of health and safety measures in the SPS Agreement means that it concerns some environmental matters, providing a sufficient linkage between the Protocol and the SPS Agreement for article 30 to be relevant.

149 WTO Committee on Trade and Environment, above n 148.

150 General Agreement on Tariffs and Trade 1994, above n 84, art 2.

151 An example is the case of Japan - Taxes on Alcoholic Beverages (4 October 1996) WT/DS/11/AB (Appellate Body).

152 Vienna Convention on the Law of Treaties, above $\mathrm{n} 57$, art 30.

153 Chris Wold "Multilateral Environmental Agreements and the GATT: Conflict and Resolution" (1996) 26 Envtl L 841, 910. 


\section{Lex posterior}

Article 30(2) of the Vienna Convention states that where there is a conflict between two treaties "the earlier treaty applies only to the extent that its provisions are compatible with those of the later treaty". This is known as the lex posterior rule.

The SPS Agreement was established in 1994, while the Protocol came into force in September 2003. It is arguable that the parties who are members of both the SPS Agreement and the Protocol have, by signing the Protocol, agreed that international trade in GMO products will be regulated by the Protocol and not by the SPS Agreements. In other words, they have waived their WTO obligations insofar as they relate to trade in GMOs.

This argument can only apply to states that are parties to both treaties, as a state that is a WTO member, but not a party to the Protocol can argue that it never gave up its rights under the WTO agreements, and could insist on exporting GMOs to another WTO member country. In such a situation the importing country would not be able to rely on the Protocol and would have to involve the WTO exceptions if it wished to refuse the imports.

\section{The more specific treaty?}

Although not stated in the Vienna Convention the general principle of law known as lex specialis holds that a more specific treaty trumps a more general treaty. Thus it could be argued in relation to GMOs that the Protocol, dealing only with biodiversity, is much more specific than the SPS Agreement, which relates to health and safety measures generally. ${ }^{154}$

Significantly, the CTE has suggested that the lex specialis principle would very likely be taken into account by the WTO, should it have to deal with an MEA. The CTE holds the view that trade measures that parties have agreed to in an MEA should prevail over WTO provisions. ${ }^{155}$ However, given that views of the CTE are not binding on the WTO, this is not a definitive interpretation.

\section{What happens if disputing parties are not members of both agreements?}

If a dispute were to arise between two countries such as the United States, which is a WTO member and not a Protocol member, and New Zealand, which is a member of both, the terms of the SPS Agreement would prevail under article 30(4)(b) of the Vienna Convention. In this situation it would be unlikely that the Protocol would play any part in the decision of the WTO. This conclusion provides a strong incentive for the United States not to sign the Protocol, which would safeguard its existing rights under the WTO.

154 Wold, above n 153, 912.

155 WTO Committee on Trade and Environment, above n 148. 
It can be concluded that, on the basis of the Vienna Convention, between parties to both the WTO and the Protocol, the WTO will apply only to the extent that its provisions are compatible with those of the Protocol due to the lex posterior rule. Between a party to both the WTO and the Protocol, and a party to only one of those treaties, the WTO would govern all their mutual rights and obligations. ${ }^{156}$

\section{E The Precautionary Principle - Is it Customary International Law?}

While the United States could challenge the relevance of the Protocol to any dispute to which it is a party, New Zealand could argue that the Protocol is still relevant because it articulates customary international law in its formulation of the precautionary principle. The principles of customary international law override the provisions of the WTO agreements, even if customary international law develops later than the agreements. ${ }^{157}$ If this were the case then the WTO would be bound to rule in accordance with the precautionary principle, even if neither party to the dispute were parties to the Protocol.

Many commentators have argued that the entry into force of the Protocol will contribute to the precautionary principle achieving the status of customary international law. ${ }^{158}$ This is what the EU tried to argue in the Beef Hormones case. The next part of this article considers the requirements for the development of a principle of international customary law.

\section{F Customary International Law}

Customary international law is developed through state practice and opinio juris. Opinio juris is satisfied where a state follows a practice because it feels that it is legally obliged to do so. Treaties that are ratified by a large number of states often contribute to the development of customary international law by articulating conduct that is followed by many states. ${ }^{159}$ Once a treaty articulates customary international law it becomes binding on all states, even those not party to the agreement. ${ }^{160}$

A lapse of time is usually required for a principle to become one of customary international law, because the development of a principle is usually progressive. ${ }^{161}$ However, such a period need not be particularly long. A rule in a treaty might develop into a principle of customary international law

156 T O Elias The Modern Law of Treaties (Oceana Publications Inc, New York, 1974) 57.

157 Elias, above n 156, 57.

158 Stewart and Johanson, above n 34, 40.

159 Mark E Villiger Customary International Law and Treaties (2nd ed, Kluwer, The Hague, 1997) 258.

160 Villiger, above n 159, 258.

161 Villiger, above n 159, 259. 
very quickly, by having widespread participation and by being supported by states that are substantially affected. ${ }^{162}$

In 2000 , in a communication to the WTO, the European Commission claimed that the precautionary principle had become a "fully fledged principle of international law". ${ }^{163}$ The European Commission described the precautionary principle as one that had been progressively consolidated in international environmental law, and claimed that the WTO agreements confirmed this. The basis for this claim by the European Commission was that each member of the WTO should have the exclusive right to determine the level of environmental protection that they considered appropriate in relation to GMOs. The European Commission, citing the Beef Hormones decision, claimed that the precautionary principle was sanctioned by article 5(7) of the SPS Agreement which, as discussed above, allows the precautionary principle on a provisional basis only, and should not be "bound up with a time limit". 164

The European Commission noted that "recourse to the precautionary principle is a central plank of EU policy". 165 The European Commission also noted, somewhat cryptically, that the communication would not be the "last word" on this topic. ${ }^{166}$

However, while there are strong arguments that the precautionary principle is now one of customary international law, the fact that the United States has not ratified the Protocol has the likely effect of preventing the principle from developing into one of customary international law at this time. ${ }^{167}$

\section{G What does this mean for MEAs in General?}

What can be concluded is that currently, on a strict interpretation, any restrictive action pursuant to the Protocol could breach the WTO rules. Unless the WTO decides to recognise the legitimacy of the Protocol, a claim by the United States against New Zealand would probably succeed at the WTO. The Protocol's only chance at the WTO would be if both parties to the dispute were members of the Protocol and the Vienna Convention becomes relevant. However, the fact that the precautionary principle does seem to be developing into a principle of customary international law means that this situation could well change in the future.

\footnotetext{
162 Villiger, above n 159, 260.

163 WTO Communication from the European Communities on the Precautionary Principle (G/SPS/GEN/168, Geneva, 2000) 9.

164 Communication from the European Communities on the Precautionary Principle, above n 163, 9.

165 Communication from the European Communities on the Precautionary Principle, above n 163, 10.

166 Communication from the European Communities on the Precautionary Principle, above n 163, 10.
}

167 Stewart and Johanson, above n 34, 43. 


\section{H Where does this Leave the Protocol?}

The conclusion above is problematic considering the large number of MEAs that use trade measures to protect states from substances that are harmful to the domestic environment. These include the Basel Convention on the Control of Transboundary Movements of Hazardous Waste, the Convention on International Trade in Endangered Species of Wild Flora and Fauna and the Montreal Protocol on Substances that Deplete the Ozone Layer. ${ }^{168}$ The Protocol is already serving as an international precedent for future MEAs addressing trade, risk assessment, and risk management. ${ }^{169}$ While the precise relationship between MEAs and the WTO varies, together they show that trade restrictions are an essential element in the imposition of environmental policy.

One commentator concludes that the various conflicts between MEAs and the WTO demonstrate that there is a real problem with the rigid separation in international law of public international law, of which MEAs form part, and international economic law. ${ }^{170}$ At present the WTO system is too narrow to encompass an environmental perspective, which is understandable given that it was created 50 years ago when the significance of environmental concerns had not been identified. Another commentator described the WTO as "disturbingly anti-environmental."171

It is the view of the United Nations Environment Programme that the current WTO dispute mechanisms are probably not sufficient to deal with a dispute concerning an MEA and therefore, "there is an urgent need to have appropriate mechanisms put in place". ${ }^{172}$ But what should these mechanisms be?

If the WTO is left to decide how to accommodate the Protocol, or any other MEA, into international trade regulation, it is likely that the environment will come out the loser. The WTO has acknowledged that it is only competent to deal with trade issues. The WTO was set up as an organisation to prevent limitations on trade and, accordingly, its overriding task is to look at environmental policies that have a significant impact on trade. For these reasons it is likely that the

168 Basel Convention on the Control of Transboundary Movements of Hazardous Waste (22 March 1989) ILM 657; Convention on International Trade in Endangered Species of Wild Flora and Fauna (6 March 1973) 12 ILM 1085; Montreal Protocol on Substances that Deplete the Ozone Layer (16 September 1987) in (1993) 21 Intl Envt Rep 3151.

169 Paul E Hagen and John Barlow Weiner "The Cartagena Protocol on Biosafety: New Rules for International Trade in Living Modified Organisms" (2000) 12 Geo Int'l Envtl L Rev 697, 699.

170 Macmillan, above n 29, 42.

171 Ryan Winter "Reconciling the GATT and the WTO with Multilateral Environmental Agreements: Can We Have Our Cake and Eat It Too?" (2000) 11 Colo J Int'1 Envtl L \& Pol'y 223, 238.

172 The United Nations Environment Project "Chairman's Summary" (UNEP Meeting on Compliance, Enforcement and Dispute Settlement in Multilateral Environmental Agreements and the World Trade Organisation, Palais de Nations, 26 June 2001). 
WTO will not favour the precautionary principle as articulated in the Protocol, and will prefer a policy where scientific proof is needed to justify restrictions on trade.

Given the problems that would be associated with the WTO interpreting the Protocol, and the emotionally charged nature of the GE debate generally, it would be clearly risky for the decision in a dispute over the trade in GMOs to be made by the WTO. One commentator predicts that any ruling by the WTO on the issue would be "politically controversial, technically complex and doctrinally perplexing"173 and would provoke enormous political fallout. He concludes that such a dispute would call into question not only the Protocol but also the legality of all trade bans enshrined in MEAs, and would have a disastrous effect on the legitimacy of the WTO.

To avoid that outcome the WTO needs to address the issue of GMOs and trade restrictive measures in MEAs generally and not on a case-by-case basis.

\section{THE RESPONSE OF THE WTO TO THE CONFLICT}

The conflict between WTO rules and MEAs has long been recognised by the WTO. The CTE states in its terms of reference that it aims to "identify the relationship between trade measures and environmental measures, in order to promote sustainable development". ${ }^{174}$

At the time of its creation there was much hope that the CTE would have the ability to reconcile the problems between trade and the environment. ${ }^{175}$ However that optimism has been largely unfounded. The CTE has never been given the competence to revise WTO rules in order to accommodate environmental goals. On the contrary, the work of the CTE has been restricted to nonbinding recommendations and reports. The CTE has been institutionally separated from the WTO committees that have responsibility for the development of WTO agreements. ${ }^{176}$ One commentator has described the work of the CTE as "non-aggressive and uninspiring". 177

Despite focusing on the environment, the CTE is still part of the WTO and thus its focus is primarily on the trade impacts of environmental measures, not on the environmental impacts of

173 Grosko, above n 121, 327.

174 WTO Decision on Trade and Environment (Adopted by Ministers at the Meeting of the Uruguay Round Trade Negotiations Committee, Marakesh, 1994).

175 Macmillan, above n 29, 14.

176 "The State of Trade Law and the Environment: Key Issues for the next Decade", above n 127, 5.

177 Winter, above n 171, 241. 
trade rules. ${ }^{178}$ The WTO has described the work of the CTE as based on two fundamental principles: 179

(1) The WTO is only competent to deal with trade. In other words, in environmental issues its only task is to study questions that arise when environmental policies have a significant impact on trade.

(2) The WTO is not an environmental agency.

The CTE has been powerless to take any decisive action in favour of the environment because states regularly insist on the WTO's limited competence to deal with environmental issues whenever an environmental issue has the potential to disrupt their economic interests. Since 1996 the CTE has met only three times per year and has produced few substantive reports. This may be explained in part by the fact that the most active participant at the CTE is the United States. ${ }^{180}$ The CTE has made no conclusions on the relationship between the Protocol and the WTO but has acknowledged that it is something that the WTO must look into. ${ }^{181}$

\section{A Doha and Cancun}

The relationship between the WTO and MEAs was raised at both the Fourth WTO Ministerial Conference, held in Doha, Qatar in 2001 and the Fifth WTO Ministerial Conference, held in Cancun, Mexico in 2003. ${ }^{182}$

At Doha a number of parties, especially the EU, emphasised the need for resolution between the two systems. The Protocol was used as an example of where such a relationship needs to be addressed. In a major coup for the EU the Ministerial Document produced from the Doha meeting included a clause mandating negotiations on trade and the environment. This seemed revolutionary as it made the environment a negotiating item, rather than just a CTE "study item" as had been the custom in the past. ${ }^{183}$

178 Gregory Shaffer "The World Trade Organisation Under Challenge: Democracy and the Law and Politics of the WTO's treatment of Trade and Environmental Matters" (2001) 25 Harv Envtl L Rev 1, 24.

179 Shaffer, above n 178, 20.

180 Shaffer, above n 178,45 .

181 WTO "Beyond the Agreements: The Environment - a new higher profile" available at $<$ http://www.wto.org $>$ (last accessed 1 July 2005).

182 The Sixth WTO Ministerial Conference will be held in Hong Kong from 13 to 18 December 2005. The main task was to take stock of progress in negotiations and other work under the Doha Development Agenda.

183 "The State of Trade Law and the Environment: Key Issues for the next Decade", above n 127, 7. 
The Ministerial document sets out, at paragraph 31(i), that such negotiations will address "[t]he relationship between international trade agreements and MEAs." 184 These negotiations will be aimed at enhancing the "mutual supportiveness" between trade agreements and MEAs. ${ }^{185}$ However, a major concession to those who opposed such discussions was the inclusion of "without prejudice to their outcomes" in the clause that mandated the negotiations. ${ }^{186}$

Another limitation of the effectiveness of the negotiations is the inclusion of paragraph 32 in the Ministerial document, which clearly limits the scope of work under paragraph 31 by preventing any changes to the legal rights and obligations of WTO members.

One commentator has claimed that paragraph 31, far from endorsing MEAs, actually limits the ability of the Appellate Body to respond to WTO conflicts with MEAs, by taking responsibility away from the Appellate Body and giving it to WTO members. ${ }^{187}$ Another point to note is that there was no mention of the precautionary principle at the Doha meeting by any of the delegates and accordingly, no reference to it in the resulting Ministerial Document.

In any case, there has been little action taken in relation to paragraph 31 of the Doha Ministerial Document. In November 2002, officials from the WTO and various MEA secretariats, including the secretariat for the Protocol, met to discuss how to structure negotiations under paragraph 31(i) of the Ministerial Document. Most of the resulting conclusions did not involve any new action. Rather, the focus was on information exchanges and sharing of ideas, and not on any concrete progress.

Prior to the Cancun Ministerial Conference in 2003, the Chairperson of the CTE submitted a report on the status of the negotiations it mandated. ${ }^{188}$ That report noted that, since the negotiations were launched, delegations had "actively engaged in developing a common understanding of the mandate" which had evolved from two specific mandates: to identify specific trade obligations in MEAs and conceptualise a discussion of the relationship between the WTO and MEAs.

At Cancun, parties evaluated the progress of negotiations and other work under the Doha Development Agenda. In relation to MEAs, the Draft Cancun Ministerial Text distributed at the Cancun Ministerial Conference on 13 September 2003, states simply that the parties "...reaffirm (their) commitment to these negotiations". 189

184 WTO Doha Ministerial Declaration (WT/MIN(01)/DEC/1, Geneva, 2001) para 31(i).

185 Doha Ministerial Declaration, above n 184, para 31(i).

186 Doha Ministerial Declaration, above n 184, para 31(i).

187 "The State of Trade Law and the Environment: Key Issues for the next Decade", above n 127, 35.

188 Report of the Chairperson of the CTE Special Session to the Trade Negotiations Committee (15 July 2003) TN/TE/7 and Suppl.

189 Report of the Chairperson of the CTE Special Session to the Trade Negotiations Committee, above n 188. 
The limited results from the WTO in general, and particularly the CTE, demonstrate that it may be hard to deal with the conflict within the confines of the WTO. However, the fact that the WTO is so powerful in terms of its binding disputes settlement and enforcement mechanisms, means that the Protocol, with no dispute resolution body of its own, is particularly vulnerable. Solutions may need to be part of the WTO system in order to avoid being overwhelmed by the political might of the WTO. At the 1999 Seattle anti-globalisation protests one banner proclaimed "God is Dead. The WTO replaced it". 190

The WTO system is currently unable to cope with environmental measures that create restrictions on trade. The final part of the article will look at possible ways to reform the WTO.

\section{WTO REFORM}

There have been many suggestions as to how the WTO could be reformed to better meet environmental needs. One commentator concludes that the WTO system could be amended to provide an exception for environmental purposes in MEAs. ${ }^{191}$ The challenge is to establish an exception that has clear boundaries so to prevent it from being used as a protectionist device. ${ }^{192}$

\section{A Amendment and Waiver}

Any member of the WTO may initiate a proposal to amend the provisions of one of the WTO Agreements by submitting a proposal to the Ministerial Conference of the WTO. There needs to be a two thirds majority of all WTO members for the proposal to be submitted to the WTO, and acceptance of all members is required for the proposal to be successful. ${ }^{193}$ This requirement of unanimity has meant that, to date, WTO parties have been unable to come to any agreement over whether, and if so how, to amend the various WTO agreements to better deal with the environment. 194

Some commentators have raised the possibility of using the WTO's waiver procedure as an alternative to the need for consensus to amend the agreements. The North American Free Trade Agreement could be used an example of a trade body that has waived obligations for specific MEAs. ${ }^{195}$ The WTO system provides for a waiver process which is reasonably efficient. The WTO

190 Stenzel, above n 113, 20.

191 John H Jackson The Jurisprudence of GATT and the WTO (Cambridge University Press, Cambridge, 2000) 432.

192 Jackson, above n 191, 432.

193 Marrakech Agreement Establishing the WTO (1994) 33 ILM 1168, art X.

194 Wold, above n 153, 921.

195 Article 104 of NAFTA lists seven MEAs that trump NAFTA in the case of disagreement. The seven MEAs are the Montreal Protocol, the Basel Convention, CITES, and four bilateral treaties. 
Agreement explicitly allows parties to waive WTO obligations in exceptional circumstances, if such waiver is approved by a three-fourths majority of WTO parties. ${ }^{196}$ The Protocol could be submitted to the WTO for waiver, meaning that to the extent acting in accordance with the Protocol would breach a party's WTO obligations, those obligations would be waived. However, because of the strong influence of the United States at the WTO, it is unlikely that a three-fourths majority could be achieved. Further, it is accepted that waiver is supposed to be used only in exceptional circumstances and should always have a termination date. ${ }^{197}$ Thus, waiver could only ever be a temporary solution to the MEA problem.

\section{B Interpretation}

A member country could submit an application to the General Council of the WTO requesting an authoritative interpretation of the relationship of the WTO Agreements with the Protocol in order to avoid future conflicts. The Ministerial Agreement provides that: ${ }^{198}$

The Ministerial Conference and the General Council shall have the exclusive authority to adopt interpretations of this Agreement and of the Multilateral Trade Agreements. The decision to adopt an interpretation shall be taken by a three-fourths majority of the Members.

This same approach could be used to reconcile the provisions of the WTO Agreements with other MEAs that involve trade restrictions. This sort of interpretation may find more legitimacy with the international community than ad hoc Panel interpretations and would help parties to both agreements to understand their obligations.

However, the United States would probably block any agreed interpretation by consensus in the General Council. Another danger is that such an interpretation would be couched in the same kind of ambiguous language as the savings clause in the Protocol.

It has been suggested that in June 2000 the legal division of the WTO secretariat proposed that the General Council of the WTO provide an interpretation of the WTO agreements and their interaction with the Protocol in order to avoid future conflicts and uncertainty. ${ }^{199}$ There is, however, no accessible information on what became of this proposal. It seems likely that it was simply ignored.

196 Stenzel, above n 113, 29.

197 Marrakech Agreement Establishing the WTO, above n 193, art IX(4).

198 Marrakech Agreement Establishing the WTO, above n 193, art IX(2).

199 Chakravarthi Raghavan "Reconciling Biosafety Protocol and WTO by Interpretation?" (SUNS South-North Development Monitor, Geneva, 2000). 


\section{The EU's Suggestion}

One recent suggestion by the EU in relation to the conflict between MEAs and the WTO involved amending the GATT so that MEAs are clearly covered in the article XX exceptions. article XX would include a proviso that any measures taken under specific provisions of an MEA "shall be presumed to be necessary for the achievement of the environmental objectives of the MEA" or, alternatively, "necessary for the protection of the environment" and thus would not be subject to the strict tests imposed by the WTO agreements in relation to environmental exceptions.

The major issue in relation to this proposal is how to categorise an MEA to prevent the exception being used as a protectionist instrument by developed countries to limit imports from the developing world. One way to avoid this would be to require any exempt MEA to be open to participation by all parties concerned with the environmental objectives of the agreement and reflective of a representative range of countries. This suggestion was addressed by the WTO in its World Trade Report for 2003. ${ }^{200}$ The WTO acknowledged that MEAs create obligations of similar standing to WTO obligations. ${ }^{201}$ The report went no further than mentioning the suggestion. This may or may not indicate that the suggestion is something that the WTO is looking into.

\section{CONCLUSION}

The Protocol goes a long way to reconciling trade and environmental objectives and its elaboration of the precautionary principle is a major contribution to international environmental law. However, the Protocol faces a major obstacle: the WTO also regulates the trade in GMOs and the two systems conflict. The Protocol provides that parties can use the precautionary principle to manage the risks associated with trade in GMOs. The SPS Agreement on the other hand, requires scientific justification for any trade restrictive measure that is not provisional in application.

How will the two agreements interact? The Protocol includes a savings clause that is intended to address its relationship with the WTO. However, that clause reflects the sensitivity of the compromise reached in Montreal and because of its ambiguity, resolves nothing.

Moreover, the United States has indicated that it does not accept the precautionary principle as a basis for restricting international trade. The United States, like the WTO, insists on scientific justification for any trade restrictive measure.

Importing countries should be mindful that any action taken pursuant to the Protocol risks a case being taken to the WTO. A possible solution to the conflict between the Protocol and the SPS Agreement is using the Protocol as evidence of international standards in relation to GMOs and biodiversity. Under the SPS Agreement parties that act consistently with such standards are

200 "World Trade Report", above n 144.

201 "World Trade Report", above n 144. 
"deemed to be consistent" with the SPS Agreement. Therefore, any action pursuant to the Protocol would be held to be consistent with WTO rules.

Such an approach is, however, unlikely to be successful. The SPS Agreement specifically identifies Codex, as the international body which creates standards for food safety under the SPS Agreement. Codex in the throes of a political stalemate, may be unable to come to any agreement over standards for GMOs. Under the SPS Agreement, where there are no international standards in place, members must justify any trade restrictions on the basis of a narrowly focused risk assessment. It is likely that the United States would be involved in any future dispute over GMOs. Because the United States is not a party to the Protocol, the Protocol could be ignored by the WTO in such a dispute. This would undermine both the Protocol and the WTO system, and would force the import of GMOs into parties to the Protocol, making the Protocol redundant. For this reason, it is preferable to address the conflict between the Protocol and the WTO as soon as possible, before such a dispute arises.

The above problem is not limited to the Protocol. There are a number of MEAs which use trade restrictive measures for environmental purposes that likely violate WTO rules. The WTO has been conscious of this problem since the formation of the CTE in 1994. However, there has been very little substantive progress by the WTO resolving the conflict mainly due to the WTO's strong almost exclusive - trade focus, and its inability to address environmental issues. However, because the WTO is so powerful, any solution to the conflict between the WTO and the Protocol (and MEAs in general) must be sanctioned by the WTO or risk being undermined. There are a number of ways in which this could be achieved: the WTO could provide an interpretation of the Protocol or as suggested by the EU, the exception in article XX of GATT could be amended so that certain MEAs are deemed consistent with WTO Agreements.

The latter would have the desirable effect of taking any action pursuant to the Protocol out of the hands of the WTO. However, care would need to be taken in the categorisation of MEAs to prevent developed countries from using the exception as a protectionist instrument to limit imports from the developing world. Further, such a categorisation would need to factor in geographical representation in membership, and the inclusion of all states with interests at stake with the issue. This creates issues for the Protocol because, although the United States has substantial interests in GMOs, it is not a party to the Protocol.

With the Protocol having entered into force, the issue of GMOs has become even more emotive and politicised. ${ }^{202}$ The WTO must take action to deal with the inevitable conflict that the Protocol has created. The challenge is to achieve a solution which is both faithful to the environmentally

202 A campaign was launched on 11 September 2003 (the date that the Cartagena Protocol on Biosafety entered into force) called "Bite back: WTO hands off our food". The aim of the campaign is to force the WTO to deal with the issue of GE in a way that is consistent with the protection of the environment and consumer choice. 
focussed and heavily precautionary Protocol, and palatable to the WTO, an organisation preoccupied with free trade and dominated by a country with a vested interest in the unrestricted trade of GMOs. 